\title{
Large-scale mantle metasomatism: a Re-Os perspective
}

\author{
John Chesley ${ }^{\mathrm{a}, *}$, Kevin Righter $^{\mathrm{b}}$, Joaquin Ruiz ${ }^{\mathrm{a}}$ \\ a Department of Geosciences, University of Arizona, Tucson, AZ 85721, USA \\ b Johnson Space Center, Mail Code ST, 2101 NASA Rd. 1, Houston, TX 77058, USA
}

Received 20 November 2002; received in revised form 18 March 2003; accepted 1 December 2003

\begin{abstract}
There is a debate on the behavior of Re and Os during mantle metasomatism. Some argue that the mantle can acquire high ${ }^{187} \mathrm{Os} /{ }^{188} \mathrm{Os}(0.15$ to $>1.0)$ either directly from metasomatic events or by the growth of ${ }^{187} \mathrm{Os}$ from ${ }^{187} \mathrm{Re}$ over time. However, any suggestions of subduction-related Os metasomatism producing whole-scale elevation of the mantle to ${ }^{187} \mathrm{Os} /{ }^{188} \mathrm{Os}$ values greater than 0.15 need to be supported by comparisons of increased $\mathrm{Re}$ and $\mathrm{Os}$ concentrations and isotopic ratios, with like and consistent increases in elements (i.e., Ba, B, Rb) and isotopic ratios (i.e., $\mathrm{Nd}, \mathrm{Pb}, \mathrm{Sr}$ ) known to be affected by metasomatic processes. All of the samples in the literature, either xenoliths or minerals (sulfides, pyroxene, phlogopite or amphibole) that are thought to represent the products of mantle metasomatism, follow a clear correlation of increasing Re/Os with decreasing Os concentration. This inverse correlation requires enrichment in Os concentrations in the metasomatizing agent by two to four orders of magnitude relative to the original subduction component in order to substantially elevate ${ }^{187} \mathrm{Os} /{ }^{188} \mathrm{Os}$, eliminating sediment or slab melts as an effective metasomatic component. To date there is no evidence to support conclusions that Os metasomatism, either directly or by a two-stage process involving Re metasomatism and ${ }^{187}$ Os growth over time, will substantially change the ${ }^{187} \mathrm{Os} /{ }^{188} \mathrm{Os}$ of the mantle to values $>0.15$. When other isotopic systems are considered along with Os, in metasomatism-based models, these models are not plausible. Consequently, large-scale mantle melts should reflect near-chondritic values. The recognition of the robustness of the Re-Os system will allow for the discrimination of different mantle and crustal reservoirs involved in magmatic processes.
\end{abstract}

(C) 2004 Elsevier B.V. All rights reserved.

Keywords: rhenium; osmium; metasomatism; subduction fluids; mantle melt

\section{Introduction}

The ability to decipher the source of melts and the role of assimilation is critical to fully understand magmatic processes. Unfortunately, it has

\footnotetext{
* Corresponding author.

E-mail address: jchesley@geo.arizona.edu (J. Chesley).
}

not always been possible to adequately unravel the original melt source from the subsequent evolution of a melt utilizing current elemental and isotopic systems. Most geochemical tracers applied to date (i.e., $\mathrm{Sr}, \mathrm{Nd}$ and $\mathrm{Pb}$ ) yield equivocal data. These elements are depleted from the mantle during melting and are mobile during subductionrelated processes, resulting in a mantle with some geochemical and isotopic characteristics similar to the crust (e.g., [1]). For example, potential sources 
of melts for large igneous provinces are commonly attributed to either mantle plumes, asthenospheric mantle contaminated by fluids or sediments during subduction events and/or melting of a previously metasomatized subcontinental lithospheric mantle (SCLM). These mantle melts may be further altered through fractionation and/or assimilation of a crustal component (either lower or upper crust) or assimilation of the SCLM (Fig. $1)$.

Currently, there is significant debate on the behavior of $\mathrm{Re}$ and Os during mantle metasomatic events. Early investigations utilizing $\mathrm{Re}$ and $\mathrm{Os}$ suggested that the system was relatively unaffected by metasomatism (e.g., [2,3]). This behavior was thought to be the consequence of the incompatible nature of $\mathrm{Re}$ during mantle melting, whereas Os behaves as a compatible element. The results are melts with low Os and high $\mathrm{Re}$ concentrations and a residual mantle with high Os and low Re concentrations. The high Os concentrations in the mantle $(\sim 1-9 \mathrm{ppb})$ and the low

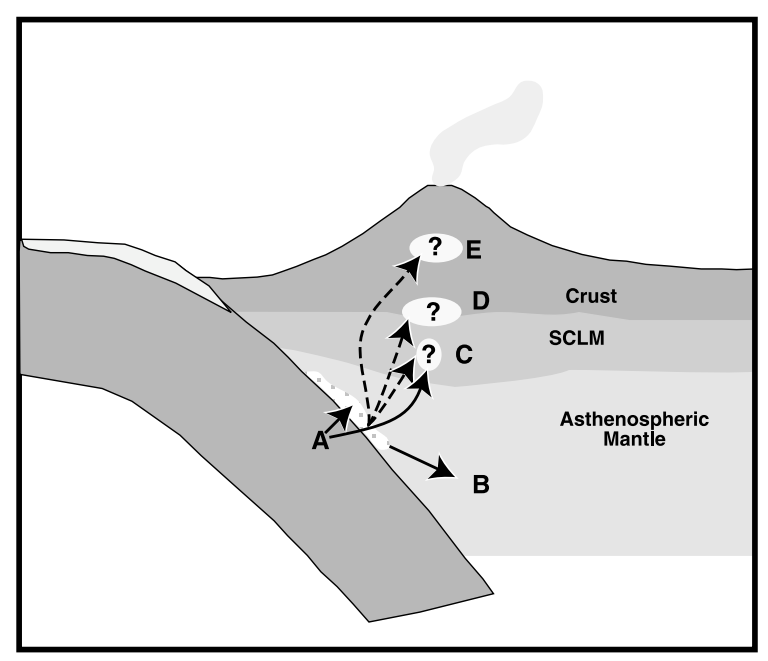

Fig. 1. Schematic cartoon representing the subduction process. (A) Subduction fluids or melt resulting from dehydration and/or melting of the subducted slab and sediments. (B) Metasomatized asthenospheric mantle resulting from input from A. (C) Metasomatized SCLM. (D) Lower crust. (E) Upper crust. Both $\mathrm{B}$ and $\mathrm{C}$ can be metasomatized at some time in the past allowing for growth of radiogenic isotope systems over time, and are potential source regions for 'metasomatized melts'. Areas C, D and E are potential locations for assimilation and fractionation (AFC) of the metasomatized mantle melts.
Os concentration of potential metasomatic components $(0.001-0.200 \mathrm{ppb})$ were thought to preclude major modification of the Re-Os isotope system in the mantle (e.g., [4]). Subsequent studies concluded that metasomatism can alter the Re-Os system [5-7], although only to a minor degree resulting in products with a ${ }^{187} \mathrm{Os} /{ }^{188} \mathrm{Os}=0.13$ 0.15 . However, a number of recent studies have also suggested that the Re-Os system within the mantle can be modified, on a large scale, through the process of metasomatism. These studies have argued that metasomatism can produce melts with ${ }^{187} \mathrm{Os} /{ }^{188} \mathrm{Os}$ values that resemble the crust $(0.15$ to $>1.0$ ) [5,8-16]. This modification can either occur directly through subduction-related metasomatism by melts/fluids with high Os concentration and high ${ }^{187} \mathrm{Os} /{ }^{188} \mathrm{Os}$ or indirectly through timeintegrated, two-stage processes whereby previously formed metasomatic minerals (such as pyroxene, phlogopite or amphibole) with high $\mathrm{Re} / \mathrm{Os}$ are remelted and incorporated into a melt.

This study summarizes available data to understand the effect of mantle metasomatism on the $\mathrm{Re}-\mathrm{Os}$ system. We address a number of questions in order to interpret the potential effects of metasomatism on the Re-Os system. Do cryptically or modally metasomatized xenoliths have elevated ${ }^{187} \mathrm{Os} /{ }^{188} \mathrm{Os}$ or Re/Os? Which minerals (sulfide, pyroxene, phlogopite and/or amphibole) are most responsible for metasomatism of the $\mathrm{Re}-$ Os system? What time scales are required for metasomatized mantle peridotite to acquire elevated ${ }^{187} \mathrm{Os} /{ }^{188} \mathrm{Os}$ through the decay of ${ }^{187} \mathrm{Re}$ ? What is the variation in ${ }^{187} \mathrm{Os} /{ }^{188} \mathrm{Os}$ expected from mantle melts?

\section{Discussion}

\subsection{Mantle xenoliths}

The data show that $\mathrm{Re}$ and Os concentrations and ${ }^{187} \mathrm{Os} /{ }^{188} \mathrm{Os}$ in mantle xenolith samples are relatively uniform despite a large variation in age and location. SCLM peridotites from Archean cratons, which have undergone repeated episodes of subduction and rifting, still maintain subchondritic ${ }^{187} \mathrm{Os} /{ }^{188} \mathrm{Os} \quad(<0.13)$ values (e.g., 
$[4,17])$. Mantle xenoliths from the Paleozoic through Mesozoic are also typically subchondritic [17-19]. Peridotites from the modern Izu-BoninMariana forearc also preserve ancient subchondritic ${ }^{187} \mathrm{Os} /{ }^{188}$ Os values [14].

There are, however, a few notable exceptions of mantle xenoliths with suprachondritic ${ }^{187} \mathrm{Os} /{ }^{188} \mathrm{Os}$. It was first suggested by $[5,20]$ that suprachondritic ${ }^{187} \mathrm{Os} /{ }^{188}$ Os $(\sim 0.13-0.14)$ in mantle xenolith samples were the result of recent subduction-related metasomatism. Six lherzolite and harzburgite xenoliths from the Kamchatka arc [21] and one lherzolite xenolith sample from within the Sierra Nevada arc [22] have been reported with ${ }^{187} \mathrm{Os} /{ }^{188} \mathrm{Os}$ as high as $\sim 0.15$. Although these samples are suggested to result from subductionrelated Os metasomatism, they have measured ${ }^{187} \mathrm{Os} /{ }^{188}$ Os values within the oceanic island basalt (OIB) field and low Re/Os ratios. All xenoliths with high ${ }^{187} \mathrm{Os} /{ }^{188} \mathrm{Os}$ within the Kamchatka arc have low Os concentrations (0.03-0.57 ppb), much less than would be expected through metasomatic overprinting by an Os-rich fluid. One sample from the Sierra Nevada arc is the only sample from the study [18] to show elevated ${ }^{187} \mathrm{Os} /{ }^{188} \mathrm{Os}$, all other samples are subchondritic despite obvious subduction metasomatic overprinting of $\mathrm{Sr}, \mathrm{Nd}$ and $\mathrm{Pb}$ [18]. This one sample contains elevated $\mathrm{S}, \mathrm{Pt}$ and $\mathrm{Pd}$ contents compared to all other xenoliths in the study and led [18] to the conclusion that this sample experienced Os metasomatism through sulfide addition via a localized process and does not represent the overall character of the mantle wedge. Regardless of the interpretation, it is important to note that samples with elevated ${ }^{187} \mathrm{Os} /{ }^{188} \mathrm{Os}$ represent a small fraction of the xenolith population in these studies [21,22] and of xenoliths worldwide (e.g., [4,17]). In studies of mantle peridotite xenoliths, where Os metasomatism has been suggested [5,7,1923], the Re/Os ratios are less than 1, demonstrating that the $\mathrm{Re}-\mathrm{Os}$ system could not have been significantly affected by metasomatism. Moreover, there are no reported mantle peridotite samples with a measured ${ }^{187} \mathrm{Os} /{ }^{188}$ Os greater than 0.15 .

All of the mantle samples from the literature that have been suggested to represent the effects of mantle metasomatism, either by their ${ }^{187} \mathrm{Os} /$
${ }^{188}$ Os value, high $\mathrm{Re}$ concentration, or mineralogy, follow a clear correlation of increasing Re/ Os with decreasing Os concentration (Fig. 2A). This relation has been previously pointed out for igneous provinces such as mid-ocean ridge basalt (MORB), OIB and volcanic arcs [4,24,25]. Thus, in order for the source of the metasomatic ${ }^{187} \mathrm{Os} /{ }^{188} \mathrm{Os}$ to significantly increase over time because of the decay of Re, the source must have a low Os concentration (0.0001-0.01 ppb). However, all of the models that suggest Os metasomatism require high concentrations of Os (0.5-10.0 $\mathrm{ppb}$ ) in the metasomatizing agent. Because of their low concentrations of Os, this removes recycled MORB, melted slab or sediments as a via-
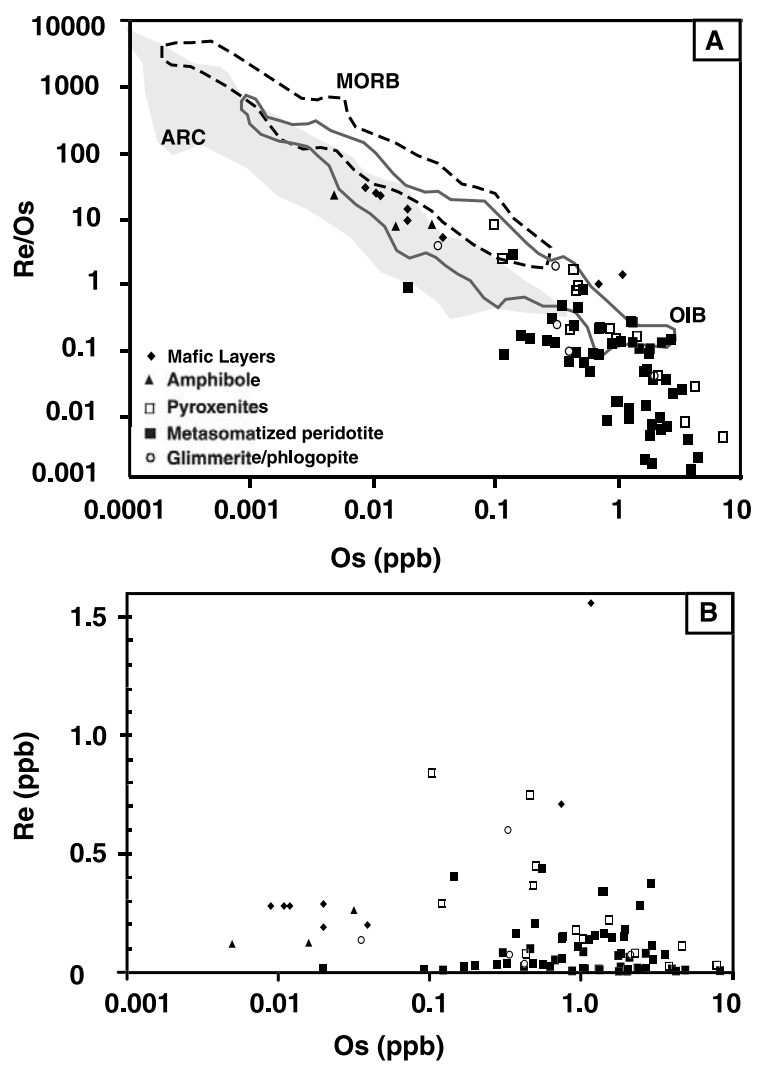

Fig. 2. (A) Diagram of Re/Os vs. Os concentration for metasomatized xenoliths and metasomatic minerals. Also shown are data for MORB, OIB and arcs [24]. Note trend of increasing $\mathrm{Re} / \mathrm{Os}$ with decreasing Os concentration for all fields. (B) Re vs. Os for mantle xenoliths and minerals. Note: low concentrations of Re, in general, for all samples. Symbols are the same as in A. 
Table 1

Median Re-Os values for different possible metasomatizing agents

\begin{tabular}{lclllcc}
\hline Lithology & $(n)$ & $\begin{array}{l}\mathrm{Re} \\
(\mathrm{ppb})\end{array}$ & $\begin{array}{l}\mathrm{Os} \\
(\mathrm{ppb})\end{array}$ & $\mathrm{Re} / \mathrm{Os}$ & ${ }^{187} \mathrm{Re} /{ }^{188}$ Os & Standard deviation \\
\hline Pyroxenites & 11 & 0.256 & 0.492 & 0.477 & 2.34 & 12.9 \\
Phlogopites/glimmerites & 5 & 0.075 & 0.336 & 0.223 & 0.747 & 0.5 \\
Amphiboles & 3 & 0.125 & 0.016 & 8.30 & 34.25 & 4.7 \\
Metasomatized xenoliths & 29 & 0.080 & 1.37 & 0.081 & 0.382 & 0.5 \\
Pyroxenite EN89-2 & & 0.367 & 0.484 & 0.758 & 3.73 & 11.6 \\
Mafic layers & 9 & 0.280 & 0.020 & 11.95 & 68.82 & \\
\hline
\end{tabular}

Pyroxenites [7,8,15,23,64-66]; phlogopite/glimmerites [7,8,67]; amphiboles (Chesley, unpublished data; [67]); metasomatized xenoliths $[5,7,23,42]$; mafic layers [68-70].

ble high ${ }^{187} \mathrm{Os} /{ }^{188} \mathrm{Os}$ contaminant to serve as a lever to change the ${ }^{187} \mathrm{Os} /{ }^{188} \mathrm{Os}$ of mantle melts (see also discussions in [26,27]).

Overall, the metasomatic minerals within mantle xenoliths show significant variability in Re and Os concentrations, although the majority of samples have Re/Os less than 10 (Fig. 2A; Table 1). More importantly, $\mathrm{Re}$ concentrations are very low, with only one sample over $1 \mathrm{ppb}$ (Fig. 2B). In order for a mantle melt to have elevated ${ }^{187} \mathrm{Os} /$ ${ }^{188} \mathrm{Os}$, the Os concentration or the ${ }^{187} \mathrm{Os} /{ }^{188} \mathrm{Os}$ of the metasomatizing agent will need to be high enough to influence the mantle. Any metasomatic mineral with high Os concentrations will have low $\mathrm{Re} / \mathrm{Os}$, thus will require long periods of time before the mineral can acquire a high enough ${ }^{187} \mathrm{Os} /$ ${ }^{188}$ Os capable altering the ${ }^{187} \mathrm{Os} /{ }^{188} \mathrm{Os}$ of potential melts (Fig. 2B). Conversely, any mineral with high $\mathrm{Re} / \mathrm{Os}$ has a low Os concentration and would be ineffective for significantly elevating Os isotopic ratios of a mantle melt, even after long periods of time (see below).

\subsection{Subduction fluids}

In order for a subduction fluid to directly influence the ${ }^{187} \mathrm{Os} /{ }^{188} \mathrm{Os}$ of the mantle the subduction component will need to have had a high Re/Os ratio for a long period of time. However, because of the negative correlation of Re/Os with Os concentration, the subduction component must have a low Os concentration. The resulting metasomatic component would therefore need to be enriched in Os concentration by two to four orders of magnitude [11,26,27], relative to the original subduction component, in order to influence the ${ }^{187} \mathrm{Os} /{ }^{188} \mathrm{Os}$ of the mantle wedge. Current evidence suggests, however, that Os is not mobile in arc environments: (1) Re-Os investigations of eclogites, blueschists and mafic granulites indicate that there is no appreciable loss of Os from the mafic protolith during dehydration [28-30]; (2) any process that would concentrate Os in the fluid should result in similar or greater enrichments of incompatible elements $(\mathrm{Sr}, \mathrm{Nd}, \mathrm{Pb})$, as well as $\mathrm{Re}$, which is not observed. Arc volcanic samples have substantially lower $\operatorname{Re}$ concentrations than MORB, OIB or sediments (e.g., [24]). Re is $10^{2}$ $10^{3}$ times more abundant than Os in the subducting component $[4,24]$ and $\operatorname{Re}$ is $10^{2}-10^{4}$ times more soluble in a Cl-rich high $f \mathrm{O}_{2}$ fluid $[31,32]$. Thus, the only reasonable conclusion from the uniform ${ }^{187} \mathrm{Os} /{ }^{188} \mathrm{Os}$ ratios in ancient cratonic lithosphere and low Re/Os ratios in metasomatized xenoliths is that subduction-related metasomatism alone cannot directly affect the ${ }^{187} \mathrm{Os} /{ }^{188} \mathrm{Os}$ of the overlying mantle wedge.

Alternatively, the ${ }^{187} \mathrm{Os} /{ }^{188} \mathrm{Os}$ value of mantle melts could be affected by metasomatic minerals, which have been emplaced into the mantle (asthenospheric or lithospheric) at some time in the past and have grown more radiogenic through the decay of ${ }^{187} \mathrm{Re}$.

Mantle sulfides have been demonstrated both experimentally [33] and in natural systems [34,35] to have a large partition coefficient for Os and a small partition coefficient for Re (Fig. 3). Accordingly, sulfides offer a potential metasomatic component to alter the ${ }^{187} \mathrm{Os} /{ }^{188} \mathrm{Os}$ of the mantle. However, sulfides make poor metaso- 

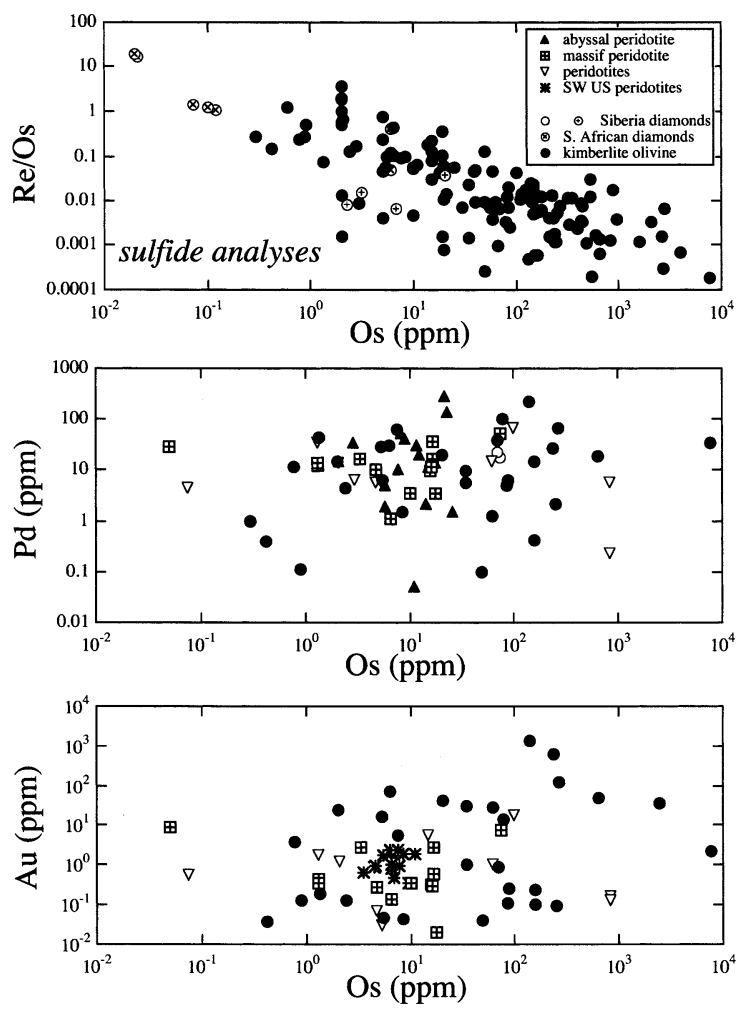

Fig. 3. Diagrams of Re/Os, Pd and Au vs. Os concentration for sulfide inclusions from diamonds, kimberlitic olivines, mantle xenoliths, massif peridotites, and abyssal peridotites. [18,40-45]. Note trends of increasing Re/Os with decreasing Os content.

matic agents for a number of reasons. First, sulfides are difficult to destabilize, FeS liquid is stable to high oxygen fugacities, partly because of the dissolution of $\mathrm{O}$ into $\mathrm{FeS}$ at higher $\mathrm{fO}_{2}[36-$ 39]. Even when $\mathrm{FeS}$ or Fe-rich monosulfide solid solutions break down at relatively high temperatures, pentlandite and chalcopyrite are stable at lower temperatures. Additionally, metasomatic sulfides commonly have high $\mathrm{Au}, \mathrm{Pd}$ and Re/Os, and are Os-poor $[18,40]$. Thus, these elements would potentially be sensitive indicators of metasomatism; however, there are no correlations of radiogenic $\mathrm{Os}$ with $\mathrm{Pd}$, or $\mathrm{Au}$ in arc rocks, or in metasomatized peridotites [41-43]. Second, metasomatized peridotite should have higher S content than fertile or unmetasomatized peridotite. Compilations of $\mathrm{S}$ contents of all peridotites indicate that all samples have $S$ contents $<300$ ppm, with no systematic low or high trend for metasomatized vs. unmetasomatized samples (e.g., [44]). Third, most in situ analyses of sulfide have resulted in ${ }^{187} \mathrm{Os} /{ }^{188} \mathrm{Os}$ ratios that are $<0.135$, and few that are $>0.135$ [40,45-48]. Indeed, some sulfide inclusions have been shown to have low ppm levels of Os and ${ }^{187} \mathrm{Os} /{ }^{188} \mathrm{Os}$ as high as 0.8 [40]. The few samples that do have values $>0.135$ also have the highest $\mathrm{Re} / \mathrm{Os}$ ratios, but the lowest Os contents (Fig. 3). Recent studies of sulfide metasomatism have shown that metasomatic sulfides contain low Os concentrations relative to primary mantle sulfides, which contain subchondritic ${ }^{187} \mathrm{Os} /{ }^{188} \mathrm{Os}$ and therefore the few samples with elevated ${ }^{187} \mathrm{Os} /{ }^{188} \mathrm{Os}$ have little effect on the ${ }^{187} \mathrm{Os} /{ }^{188} \mathrm{Os}$ of the sample $[7,23,40,49]$. For example, a weighted average of the recent Os concentration and ${ }^{187} \mathrm{Os} /{ }^{188} \mathrm{Os}$ from sulfide inclusions in kimberlitic olivines [40] yields an ${ }^{187} \mathrm{Os} /{ }^{188} \mathrm{Os}$ of $0.1085(n=95)$. And fourth, the Ni- and $\mathrm{Cu}$-rich metasomatic sulfides plot to the right of the Re/ Os-Os array of mantle samples (Fig. 2A), whereas arc rocks plot to the left, indicating that these sulfides are not appropriate metasomatizing agents for the sub-arc mantle. Hence, sulfides appear as an unlikely source of Os metasomatism capable of significantly changing the ${ }^{187} \mathrm{Os} /{ }^{188} \mathrm{Os}$ of the mantle.

\subsection{Influence of Re enrichment over time}

It may not be possible to directly influence the ${ }^{187} \mathrm{Os} /{ }^{188} \mathrm{Os}$ of the mantle through subduction processes. However, it is important to consider a model where the mantle has undergone Re enrichment through subduction processes and allowed to evolve over time. A scenario where Re addition occurs can be tested for a hypothetical mantle wedge with Os concentrations of $2.5 \mathrm{ppb}$. This model would require evolution of the mantle wedge over $\sim 100 \mathrm{Myr}$, with unreasonably high $\operatorname{Re}$ concentrations $(>20 \mathrm{ppb})$ in order for the mantle to achieve ${ }^{187} \mathrm{Os} /{ }^{188} \mathrm{Os}$ values of $\sim 0.2$ (much lower than Os isotopic values observed in arc volcanic provinces). There is strong evidence that subduction-related fluids are unlikely to carry high levels of $\operatorname{Re}$ [24]. Xenoliths from arc environments thought to have undergone metasomatism 
have low Re concentration and Re/Os [5,19,21]. In addition, because $\mathrm{Re}$ is incompatible during melting, the $\mathrm{Re}$ concentrations of primitive arc basalts should be higher than that of the source. Arc-type basalts with primitive compositions $(\mathrm{MgO}>7 \%)$ contain very low Re concentrations (10-500 ppt), considerably lower than OIB and MORB [24].

Secondary Re enrichment has been documented to be associated with silicates, such as amphibole, pyroxene and phlogopite (e.g., [7]). However, Re concentrations are low (Fig. 2B; Table 1); with one exception, the Re concentration of all samples is less than $1 \mathrm{ppb}$, with the majority less than 0.5 ppb.

In order to illustrate the possible consequence of $\mathrm{Re}$ enrichment of the mantle over time, we have constructed a model utilizing the median ${ }^{187} \mathrm{Re} /{ }^{188} \mathrm{Os}$ values for the different silicate metasomatic minerals (Table 1) and allowed these minerals to evolve over $2.5 \mathrm{Gyr}$ (Fig. 2B). With the exception of amphibole and the mafic layers in peridotite massifs, the ${ }^{187} \mathrm{Os} /{ }^{188} \mathrm{Os}$ in the different metasomatic components remains low. The metasomatized mantle xenoliths remain subchondritic. Although the end-members responsible for the isotopic characteristic of mantle melts cannot be uniquely constrained, simple two-component mixing calculations can be used to evaluate the effect of possible contaminants (Fig. 4). The modelling shows that it would be impossible to achieve the Os isotopic ratios measured in the different magmatic provinces by mixing a MORB-type source with these metasomatic minerals. In most cases the melt would need to be composed of 80 $100 \%$ of the metasomatizing agent just to reach ${ }^{187} \mathrm{Os} /{ }^{188} \mathrm{Os}$ values of $0.2-0.3$, which is lower than the observed ${ }^{187} \mathrm{Os} /{ }^{188} \mathrm{Os}$ values in the volcanic provinces (Fig. 4B). Although the $\mathrm{Re}$ and Os data for metasomatic minerals in the mantle are few in number, the actual mineral type is irrelevant because of the inverse correlation of Re/Os and Os concentration.

Our understanding of the behavior of Re in the subduction environment is currently poor, and recent qualitative arguments including both $\mathrm{Re}$ addition to the mantle wedge [50] and Re loss during degassing are important to consider
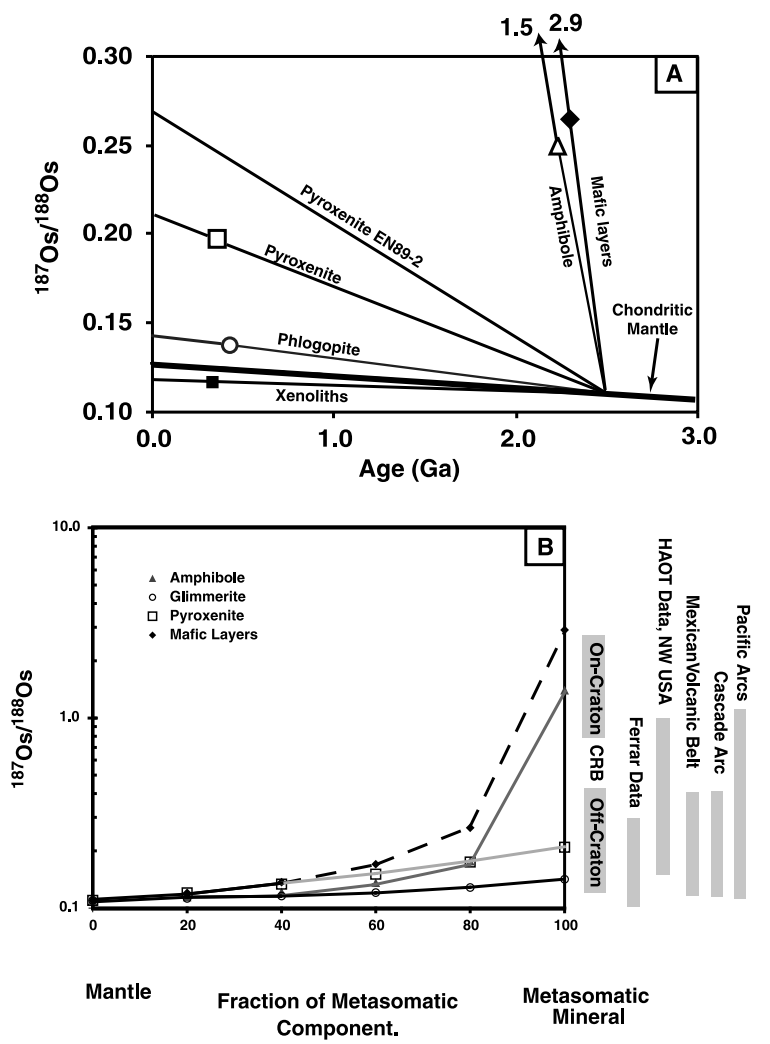

Fig. 4. (A) The variation in ${ }^{187} \mathrm{Os} /{ }^{188} \mathrm{Os}$ over time for different metasomatic end-members based on mean Re/Os ratio in Table 1. Variation in ${ }^{187} \mathrm{Os} /{ }^{188} \mathrm{Os}$ calculated using the decay constant of [57] and minerals have been allowed to grow over 2.5 Gyr. (B) Binary mixing diagram of a melt composed of MORB-type mantle source and a variable metasomatic component based on $\mathrm{A}, \mathrm{Re} / \mathrm{Os}$ ratios and concentrations from Table $1 .{ }^{187} \mathrm{Os} /{ }^{188} \mathrm{Os}$ calculated at $2.5 \mathrm{Gyr}$ (A). Xenoliths are not included in the figure, as their Re/Os ratios are subchondritic or so low that they cannot affect the mantle over any time scales. The actual mineralogy is unimportant as long as the inverse correlation between $\mathrm{Re} / \mathrm{Os}$ ratios and Os concentration (Fig. 2A) holds. Shaded fields represent variations of ${ }^{187} \mathrm{Os} /{ }^{188} \mathrm{Os}$ in different igneous provinces. Columbia River Flood Basalt (CRB) [58], Ferrar [12,59], HighAlumina Olivine Tholeiites (HAOT) [13], Trans-Mexican Volcanic Arc [12,27,59,60], Cascade Arc [11], Pacific Arcs $[9,10]$.

$[43,51,52]$. At this point these models are equivocal. In order to properly test these models, studies need to investigate other factors such as retention in the source by garnet and sulfide, and/or magmatic fractionation by magnetite and sulfide $[24,53,54]$. Sulfide saturation or undersaturation 
is a strong function of oxygen fugacity. Because the rock suites that show evidence for Re enrichment are also among the most oxidized (OIB and $\mathrm{BABB}$ ), where sulfide is likely to break down, variation in oxygen fugacity and sulfide instability can account for much of the variation observed in $\mathrm{Re}$ concentrations. In addition, investigations of arc magmas have shown increasing Re concentration correlated with increases in ${ }^{187} \mathrm{Os} /{ }^{188} \mathrm{Os}$ and indicators of fractionation (increasing $\mathrm{SiO}_{2}$, decreasing $\mathrm{Ni}$ and $\mathrm{MgO}$ ) [27], which would be unexpected if $\mathrm{Re}$ volatility played an important role in the Re concentrations of arc lavas. Until an assessment is made of these simpler and highly plausible explanations, qualitative arguments for $\mathrm{Re}$ loss during degassing and $\mathrm{Re}$ enrichment of the mantle source are premature.

\subsection{Comparisons with other isotopic systems}

In order to properly address any model for a metasomatized mantle source, it is also important to consider the effects of metasomatic veining on other isotopic systems, such as $\mathrm{Sr}, \mathrm{Pb}$ or $\mathrm{Nd}$, in addition to Os. Metasomatic fluids will be enriched in low ion lithophile (LIL) elements including $\mathrm{Rb}, \mathrm{Sr}, \mathrm{Nd}$ and $\mathrm{Sm}$. The actual enrichment in the mantle is dependent on the modal mineralogy. High $\mathrm{Rb} / \mathrm{Sr}$ ratios in phlogopite and low $\mathrm{Sm} / \mathrm{Nd}$ ratios in pyroxene will strongly affect either the ${ }^{87} \mathrm{Sr} /{ }^{86} \mathrm{Sr}$ or ${ }^{143} \mathrm{Nd} /{ }^{144} \mathrm{Nd}$ systems, respectively [55]. We can model this effect for pyroxene using an $\mathrm{Nd}-\mathrm{Os}$ mixing diagram for a SCLM that has been intruded at various points in time by pyroxenite veins (Fig. 5). We use a lithospheric mantle with Os isotopic values the same as Fig. 4 and $\mathrm{Nd}$ isotopic values similar to xenoliths measured from Simcoe, which are considered metasomatized (e.g., [5]). The isotopic values for this hypothetical mantle overlap those of modern MORB mantle. For older SCLM, it is unlikely that the ${ }^{143} \mathrm{Nd} /{ }^{144} \mathrm{Nd}$ present-day values would be so radiogenic $[1,8]$ and this value should be considered a best case scenario for metasomatic mixing models. More importantly, it is clear, because of the large variations in ${ }^{187} \mathrm{Os} /{ }^{188} \mathrm{Os}$ and ${ }^{143} \mathrm{Nd} /{ }^{144} \mathrm{Nd}$ over time, that these initial isotopic values make little difference in the overall process. The $\mathrm{Nd}$ and

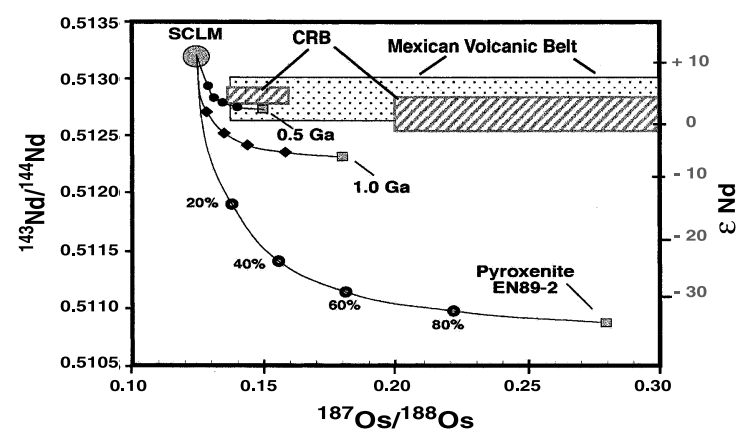

Fig. 5. Os-Nd binary mixing diagram for a mantle end-member and pyroxene EN89-2 [8] at different time periods. Data for the more evolved Grande Ronde member of the Columbia River Basalt Group and the Trans-Mexican Volcanic Belt indicate that models requiring metasomatism of the source or assimilation of a veined SCLM are not feasible. Symbols on mixing curve represent $20 \%$ increments between a SCLM and pyroxenite veins that were emplaced $0.5,1.0$ and $2.8 \mathrm{Gyr}$ before present. The arrows point to isotopic composition of the pyroxenite, if a pyroxenite with the same ${ }^{187} \mathrm{Re} /{ }^{188} \mathrm{Os}$ and ${ }^{147} \mathrm{Sm} /{ }^{144} \mathrm{Nd}$ ratios as EN82-2 was extracted from the mantle at 0.5, 1.0 and $2.8 \mathrm{Ga}$. Shaded areas represent the range of $\mathrm{Os}$ and $\mathrm{Nd}$ isotopic compositions of basalts from the Imnaha and Grande Ronde formations of the Columbia River Basalt Group [58,61] and from the Trans-Mexican Volcanic Belt $[27,60,62,63]$. SCLM $(\mathrm{Nd}=2$ ppm; $\left.\mathrm{Os}=1.0 \mathrm{ppb} ;{ }^{143} \mathrm{Nd} /{ }^{144} \mathrm{Nd}=0.5132,{ }^{187} \mathrm{Os} /{ }^{188} \mathrm{Os}=0.13\right)$, pyroxenite EN89-2 [8] $\left(\mathrm{Nd}=10 \mathrm{ppm} ; \mathrm{Os}=0.5 \mathrm{ppb} ;{ }^{147} \mathrm{Sm} /\right.$ ${ }^{144} \mathrm{Nd}=0.087, \quad{ }^{187} \mathrm{Re} /{ }^{188} \mathrm{Os}=3.7$, measured $0.510866, T_{\mathrm{DM}}$ 2.72; measured $\left.{ }^{187} \mathrm{Os} /{ }^{188} \mathrm{Os}=0.276, T_{\mathrm{BE}}=2.78 \mathrm{Ga}\right) . \mathrm{Nd}$ and Os isotopic initial values for the pyroxenite at different times are assumed to be from a depleted mantle reservoir $\left({ }^{147} \mathrm{Sm} /\right.$ $\left.{ }^{144} \mathrm{Nd}=0.2135 ;{ }^{143} \mathrm{Nd} /{ }^{144} \mathrm{Nd}=0.51315\right)$ and a bulk earth reservoir $\left({ }^{187} \mathrm{Re} /{ }^{188} \mathrm{Os}=0.4018,{ }^{187} \mathrm{Os} /{ }^{188} \mathrm{Os}=0.127\right)$, respectively.

Os isotopic values of the metasomatic end-member are the present-day measured values of a pyroxenite from the Wyoming craton [EN89-2CT, 8], which has a $T_{\text {(bulk earth) }}$ of $2.8 \mathrm{Ga}$. This sample has the highest present-day ${ }^{187} \mathrm{Os} /{ }^{188} \mathrm{Os}$ value measured in a pyroxenite. The $\mathrm{Os}$ and $\mathrm{Nd}$ isotopic values of the 0.5 and $1.0 \mathrm{Ga}$ pyroxenite are hypothetical, as if the same pyroxenite (EN89-2CT) were removed from a MORB-type mantle reservoir at these time periods and allowed to evolve to the present with the same elemental concentrations and $\mathrm{Sm} / \mathrm{Nd}$ and $\mathrm{Re} / \mathrm{Os}$.

Mixing diagrams are always limited in part by the choice of end-members. Our intent with the binary mixing model, however, is to determine if a metasomatized mantle could be a viable end- 
member for observed ${ }^{187} \mathrm{Os} /{ }^{188} \mathrm{Os}(0.15-1.0)$ ratios in continental magmatic provinces. The SCLM reservoir must be older than any metasomatizing agent; hence we chose a starting value for ${ }^{187} \mathrm{Os} /$ ${ }^{188}$ Os of 0.11 , which is the estimated value for the mantle at $2.5 \mathrm{Ga}$. The change in the mantle ${ }^{187} \mathrm{Os} /$ ${ }^{188} \mathrm{Os}$ between $2.5 \mathrm{Ga}$ and present $(0.11-0.13)$ is significantly less than the variation in any metasomatic mineral over the same time period (Fig. $4 \mathrm{~A})$. Hence the choice of the ${ }^{187} \mathrm{Os} /{ }^{188} \mathrm{Os}$ of the mantle reservoir is of little consequence. The majority of data for the Os concentration come from Archean cratons; therefore it is possible that the Os concentrations for younger lithospheric mantle may be lower. The majority of samples have Os concentrations between 1 and 9 ppb with an average of $3.5 \mathrm{ppb}$. We have chosen a minimal value of $1 \mathrm{ppb}$ for our mixing models to maximize any metasomatic effect. We recognize that the $2.5 \mathrm{Ga}$ used for metasomatic minerals is impossibly long for minerals residing in a convecting asthenosphere, and it further emphasizes the difficulty in altering the ${ }^{187} \mathrm{Os} /{ }^{188} \mathrm{Os}$ of mantle peridotite. The ${ }^{187} \mathrm{Os} /{ }^{188}$ Os for the different minerals can be determined at any age using Fig. 4A.

It is clear that emplacement of pyroxenite veins into the SCLM produces very different results for the $\mathrm{Nd}$ and Os isotopic systems. For young pyroxenite veins, it is possible to change the ${ }^{143} \mathrm{Nd} /$ ${ }^{144} \mathrm{Nd}$ of primary melts with small amounts of vein material. However, it would require over $100 \%$ of the melt from pyroxenite veining within the lithospheric mantle to reach the measured Os isotopic ratios for only the most primitive samples $\left({ }^{187} \mathrm{Os} /{ }^{188} \mathrm{Os}=0.13-0.15\right)$. However, if the pyroxenite veins were old enough to affect the Os isotopic values of a SCLM melt, the high concentrations of unradiogenic ${ }^{143} \mathrm{Nd} /{ }^{144} \mathrm{Nd}$ in the veins would be readily evident.

\section{Differentiation of mantle and crustal reservoirs}

Arc magmas represent melting of the mantle as a result of fluid addition. There are varying degrees of fluid input, which will affect both the degree of melting and initial chemistry of the melt. This in turn is overprinted by differing amounts of assimilation from potentially diverse lithospheric reservoirs (Fig. 1). Lamprophyres contain both high incompatible and compatible element contents and high volatile contents, and are argued to represent partial melts of metasomatized upper mantle (e.g., [56]). Thus lamprophyres represent an opportunity to test models for metasomatic enrichment of both $\mathrm{Os}$ and $\mathrm{Re}$ from subduction processes. For example, if Os is readily carried in subduction fluids then lamprophyric lavas should contain positive trends of LIL elements and ${ }^{187} \mathrm{Os} /{ }^{188} \mathrm{Os}$. As well, lamprophyres when compared to calc-alkaline lavas should have disproportionately elevated ${ }^{187} \mathrm{Os} /{ }^{188} \mathrm{Os}$ ratios associated with their high volatile content. However, if elevated Os isotopic ratios are the result of assimilation, then there should be a positive increase of ${ }^{187} \mathrm{Os} /{ }^{188} \mathrm{Os}$ with indicators of fractionation. Two recent Os studies of arc volcanism from western Mexico can be used for direct comparison of these two different lithologies [27,51]. The ${ }^{187} \mathrm{Os} /{ }^{188} \mathrm{Os}$ from these studies can be plotted against common indicators of metasomatism (Ba, $\mathrm{Sr}$ and $\mathrm{Pb}$ ) along with indicators of fractionation $(\mathrm{MgO}$ or $\mathrm{Ni}$; Fig. 6). Overall the lamprophyric lavas exhibit lower ${ }^{187} \mathrm{Os} /{ }^{188} \mathrm{Os}$ than the calc-alkaline suite, which is most likely the result of the higher initial Os concentration in the primary melts. It is clear from Fig. 6A that the lamprophyres have uniformly higher $\mathrm{Ba} / \mathrm{Nb}$ than the calc-alkaline lavas, which is to be expected. However, there is no correlation of increasing $\mathrm{Ba} / \mathrm{Nb}$ with increasing ${ }^{187} \mathrm{Os} /{ }^{188} \mathrm{Os}$, in fact the calc-alkaline samples with the lowest $\mathrm{Ba} / \mathrm{Nb}$ have the highest ${ }^{187} \mathrm{Os} /{ }^{188} \mathrm{Os}$. The three lamprophyre samples with the highest $\mathrm{Ba} / \mathrm{Nb}$ have some of the lowest ${ }^{187} \mathrm{Os} /{ }^{188} \mathrm{Os}(\sim 0.138)$ of any samples. A few of the lamprophyres show elevated ${ }^{187} \mathrm{Os} /{ }^{188} \mathrm{Os}$ $(\sim 0.17)$, however, the increase in ${ }^{187} \mathrm{Os} /{ }^{188} \mathrm{Os}$ is correlated with a decrease in $\mathrm{Ni}$ content and can be modelled using assimilation and fractionation (AFC) processes (Fig. 6). The AFC models require that the lamprophyres and calc-alkaline lavas originate from different source areas and/ or result from differing degrees of partial melting. Both $\mathrm{Sr}$ and $\mathrm{Pb}$ are used as common tracers of metasomatism. Sr behaves in a similar manner to $\mathrm{Pb}$, with the lamprophyres having the lowest $\mathrm{Sr}$ 

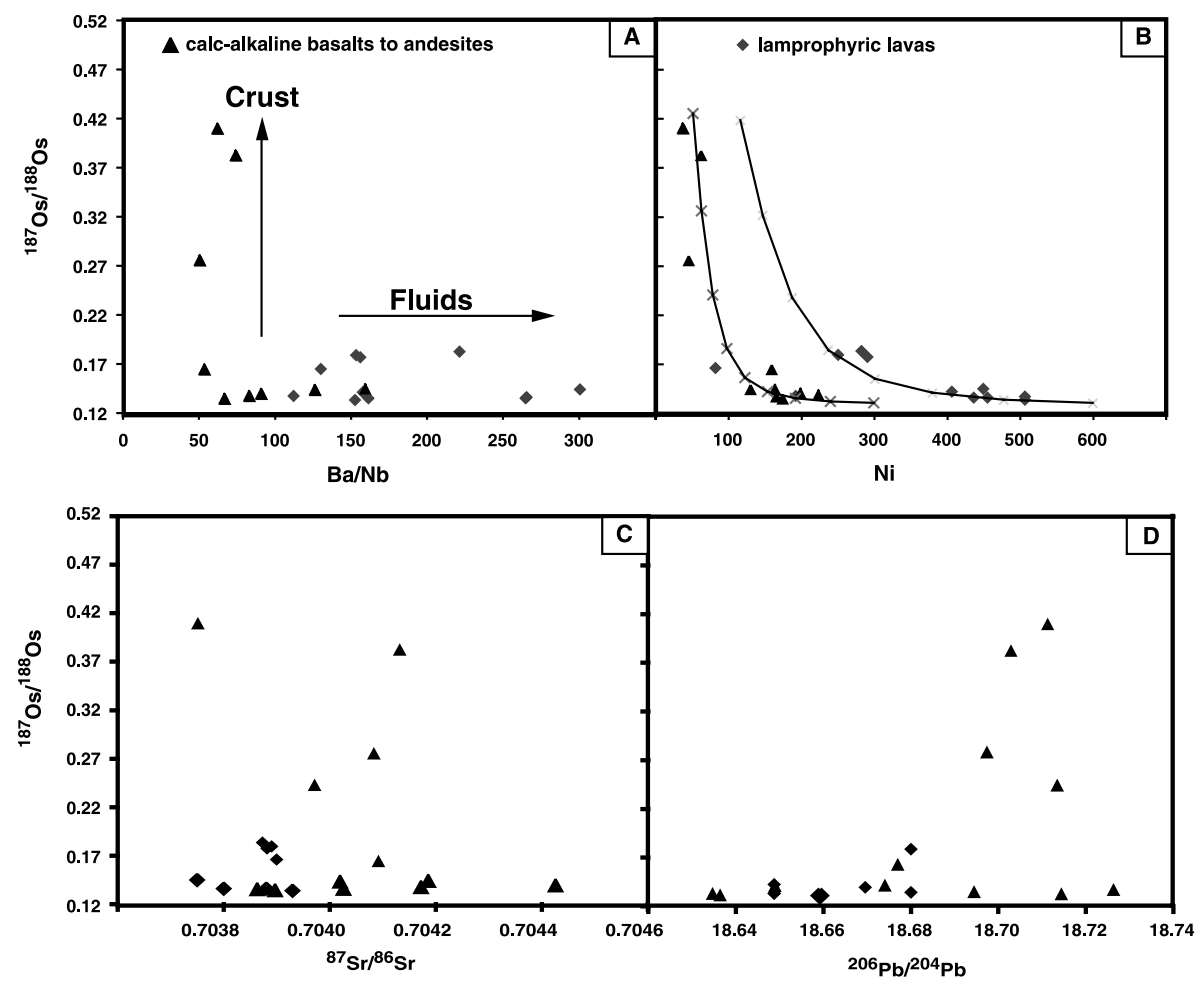

Fig. 6. $\mathrm{Ba} / \mathrm{Nb}, \mathrm{Ni}{ }^{87} \mathrm{Sr} /{ }^{86} \mathrm{Sr}$ and ${ }^{206} \mathrm{~Pb} /{ }^{204} \mathrm{~Pb}$ vs. ${ }^{187} \mathrm{Os}{ }^{188} \mathrm{Os}$ for minettes and basanites from western Mexico [57] and calc-alkaline lavas from Michoacan-Guanajuato volcanic field (triangles [27]). There is no apparent correlation between high ${ }^{187} \mathrm{Os} /{ }^{188} \mathrm{Os}$ and high $\mathrm{Ba} / \mathrm{Nb}{ }^{87} \mathrm{Sr} /{ }^{86} \mathrm{Sr}$ and ${ }^{206} \mathrm{~Pb} /{ }^{204} \mathrm{~Pb}$ ratios. AFC calculations require two separate melting events and/or different reservoirs for lamprophyric lavas and the calc-alkaline lavas. In either scenario the most primitive lavas have an initial ${ }^{187} \mathrm{Os} /{ }^{188} \mathrm{Os}$ of $\sim 0.13$, followed by subsequent assimilation within the crust. Initial starting compositions for the melts are $600 \mathrm{ppm} \mathrm{Ni}$ and $400 \mathrm{ppt} \mathrm{Os}$ for the lamprophyric lavas and 300 ppm Ni $200 \mathrm{ppt}$ Os for the calc-alkaline lavas. Data from [27,60]. Further details for AFC calculations can be found in [27]. Crosses represent increments of $2 \%$ assimilation.

isotopic ratios, and there is no correlation with ${ }^{187} \mathrm{Os} /{ }^{188} \mathrm{Os}$ (Fig. 6). The calc-alkaline suite spans the entire range of ${ }^{87} \mathrm{Sr} /{ }^{86} \mathrm{Sr}$ and the highest ${ }^{187} \mathrm{Os} /$ ${ }^{188} \mathrm{Os}$. The highest ${ }^{206} \mathrm{~Pb} /{ }^{204} \mathrm{~Pb}$ can be found in the calc-alkaline suite, but does not correlate with ${ }^{187} \mathrm{Os} /{ }^{188} \mathrm{Os}$. The lamprophyre suite contains both low $\mathrm{Pb}$ and $\mathrm{Os}$ isotopic ratios. The combination of isotopic and elemental data for the lamprophyric and calc-alkaline suites adds further support to the idea that large-scale Os metasomatism by means of subduction fluids is not a viable process. Rather, large increases in the ${ }^{187} \mathrm{Os} /{ }^{188} \mathrm{Os}$ above chondritic values are best explained by assimilation of older crustal reservoirs, and large deviations in isotopic tracers, such as $\mathrm{Pb}$ and $\mathrm{Sr}$, can be attributed to heterogeneities in the mantle.

\section{Conclusions}

The sum of evidence supports the conclusions of [3], that the Os isotopic system is resistant to large-scale metasomatism within the mantle. We do not contend that Os is unaffected by metasomatism, or that metasomatism cannot occur within the mantle on a local scale. Rather, we suggest that there is no evidence to support conclusions that Os metasomatism either directly or by a twostage process involving $\mathrm{Re}$ metasomatism and long periods of time, allowing for the growth of ${ }^{187} \mathrm{Os} /{ }^{188} \mathrm{Os}$, will substantially change the ${ }^{187} \mathrm{Os} /$ ${ }^{188}$ Os of the mantle to values $>0.15$. Additionally, any further suggestions of subduction-related Os metasomatism producing whole-scale elevation 
of the mantle to ${ }^{187} \mathrm{Os} /{ }^{188} \mathrm{Os}$ values between 0.13 and 0.15 need to be supported by comparisons of increased Os concentrations and isotopic ratios with like and consistent increases in elements (i.e., $\mathrm{Ba}, \mathrm{B}, \mathrm{Rb}$ ) and isotopic ratios (i.e., $\mathrm{Pb}, \mathrm{Sr}$ ) which are known to be affected by metasomatic processes. The fact that the Os isotopic system in the mantle is robust will allow for a better understanding of the generation of melts and crustmantle interaction.

\section{Acknowledgements}

This work is funded through NSF Grants EAR 9708361, 9814891, 9725833 and 0125773. Analytical work was undertaken in the W.C. Keck laboratory at the University of Arizona. Mark Baker was instrumental in overseeing the isotopic laboratory. The reviews of C.-T. Lee, A. Meibom, C. Hawkesworth, and an anonymous reviewer for EPSL improved the manuscript.[BW]

\section{References}

[1] C.J. Hawkesworth, P.D. Kempton, N.W. Rogers, R.M. Ellam, P.W. van Calsteren, Continental mantle lithosphere and shallow level enrichment processes in the earth's mantle, Earth Planet. Sci. Lett. 96 (1990) 256-268.

[2] R.M. Ellam, R.W. Carlson, S.B. Shirey, Evidence from the Re-Os isotopes for plume-lithosphere mixing in Karoo flood basalt genesis, Nature 359 (1992) 718-721.

[3] R.J. Walker, R.W. Carlson, S.B. Shirey, F.R. Boyd, Os, $\mathrm{Sr}, \mathrm{Nd}$, and $\mathrm{Pb}$ isotope systematics of southern African peridotite xenoliths: implications for the chemical evolution of the subcontinental mantle, Geochim. Cosmochim. Acta 53 (1989) 1583-1595.

[4] S.B. Shirey, R.J. Walker, Re-Os isotopes in cosmochemistry and high-temperature geochemistry, Annu. Rev. Earth Planet. Sci. 26 (1998) 423-500.

[5] A.D. Brandon, R.A. Creaser, S.B. Shirey, R.W. Carlson, Os recycling in subduction zones, Science 272 (1996) 861864.

[6] R.W. Carlson, F.R. Boyd, S.B. Shirey, P.E. Janney et al., Continental growth, preservation and modification in southern Africa, GSA Today 10 (2000) 1-7.

[7] J.T. Chesley, R.L. Rudnick, C.-T. Lee, Re-Os systematics of mantle xenoliths from the East African Rift: Age, structure and history of the Tanzanian craton, Geochim. Cosmochim. Acta 63 (1999) 1203-1217.

[8] R.W. Carlson, A.J. Irving, Depletion and enrichment his- tory of subcontinental and lithospheric mantle: An Os, $\mathrm{Sr}, \mathrm{Nd}$ and $\mathrm{Pb}$ isotopic study from the northwestern Wyoming Craton, Earth Planet. Sci. Lett. 126 (1994) 457-472.

[9] S. Alves, P. Schiano, C.J. Allègre, Rhenium-osmium isotopic investigation of Java subduction zone lavas, Earth Planet. Sci. Lett. 168 (1999) 65-77.

[10] S. Alves, P. Schiano, F. Capmas, C.J. Allègre, Osmium isotope binary mixing arrays in arc volcanism, Earth Planet. Sci. Lett. 198 (2002) 355-369.

[11] L.E. Borg, A.D. Brandon, M.A. Clynne, R.J. Walker, ReOs systematics of primitive lavas from the Lassen region of the Cascade arc, California, Earth Planet. Sci. Lett. 177 (2000) 301-317.

[12] C.M. Brauns, J.M. Hergt, J.D. Woodhead, R. Maas, Os isotopes and the origin of the Tasmanian dolerites, J. Petrol. 41 (2000) 905-918.

[13] W.K. Hart, R.W. Carlson, S.B. Shirey, Radiogenic Os in primitive basalts from northwestern USA: Implications for petrogenesis, Earth Planet. Sci. Lett. 150 (1997) 103116.

[14] I.J. Parkinson, C.J. Hawkesworth, A.S. Cohen, Ancient mantle in a modern arc: Osmium isotopes in Izu-BoninMariana forearc peridotites, Science 281 (1998) 20112013.

[15] B.I.A. McInnes, J.S. McBride, N.J. Evans, D.D. Lambert, A.S. Andrew, Osmium isotope constraints on ore metal recycling in subduction zones, Science 286 (1999) 512-516.

[16] B.F. Schaefer, S.P. Turner, N.W. Rogers, C.J. Hawkesworth, H.M. Williams, D.G. Pearson, G.M. Nowell, ReOs isotope characteristics of postorogenic lavas; implications for the nature of young lithospheric mantle and its contribution to basaltic magmas, Geology 28 (2000) 563566.

[17] T. Meisel, R.J. Walker, A.J. Irving, J.-P. Lorand, Osmium isotopic composition of mantle xenoliths: a global perspective, Geochim. Cosmochim. Acta 65 (2001) 1311-1323.

[18] C.-T. Lee, Platinum-group element geochemistry of peridotite xenoliths from the Sierra Nevada and the Basin and Range, California, Geochim. Cosmochim. Acta 66 (2002) 3987-4005.

[19] A.H. Peslier, L. Reisberg, J. Ludden, Os isotopic systematics in mantle xenoliths; age constraints on the Canadian Cordillera lithosphere, Chem. Geol. 166 (2000) 85-101.

[20] A.D. Brandon, G.G. Goles, A Miocene subcontinental plume in the pacific northwest, Earth Planet. Sci. Lett. 88 (1988) 273-283.

[21] E. Widom, P. Kepezhinskas, M. Defant, The nature of metasomatism in the sub-arc mantle wedge: evidence from Re-Os isotopes in Kamchatka peridotite xenoliths, Chem. Geol. 196 (2003) 283-306.

[22] C.-T. Lee, Q. Yin, R.L. Rudnick, J.T. Chesley, S.B. Jacobsen, Osmium isotopic evidence for Mesozoic removal of Lithospheric mantle beneath the Sierra Nevada, Ca, Science 289 (2000) 1912-1916.

[23] V. Olive, R.M. Ellam, B. Harte, A Re-Os isotope study of 
ultramafic xenoliths from the Matsoku kimberlite, Earth Planet. Sci. Lett. 150 (1997) 129-140.

[24] K. Righter, J.T. Chesley, J. Ruiz, Genesis of primitive arc basalt: constraints from $\mathrm{Re}$, Os and $\mathrm{Cl}$ on the depth of melting and the role of fluids, Geology 30 (2002) 619-622.

[25] J.L. Birck, C.J. Allègre, Contrasting Re-Os magmatic fractionation in planetary basalts, Earth Planet. Sci. Lett. 124 (1994) 139-148.

[26] J. Blusztajn, S.R. Hart, G. Ravizza, H.J.B. Dick, Platinum-group elements and Os isotopic characteristics of the lower oceanic crust, Chem. Geol. 168 (2000) 113-122.

[27] J.T. Chesley, J. Ruiz, K. Righter, L. Ferrari, A. GomezTuena, Source contamination versus assimilation: An example from the Trans-Mexican Volcanic Arc, Earth Planet. Sci. Lett. 195 (2002) 211-221.

[28] D.G. Pearson et al., Archean Re-Os ages for Siberian eclogites and constraints on Archean tectonics, Nature 374 (1995) 711-713.

[29] J. Ruiz, T.E. McCandless, H.H. Helmstaedt, Re-Os model ages for eclogite xenoliths from the Colorado Plateau, USA, in: J.J. Gurney, J.L. Gurney, M.D. Pascoe, S.H. Richardson (Eds.), Proceedings of the 7th International Kimberlite Conference, 2, Red Roof Publishers, Cape Town, 1999, pp. 736-740.

[30] H. Becker, Re-Os fractionation in eclogites and blueschists and the implications for recycling of oceanic crust into the mantle, Earth Planet. Sci. Lett. 177 (2000) 287300.

[31] Y. Xiong, S.A. Wood, Experimental determination of the solubility of $\mathrm{ReO}_{2}$ and dominant oxidation state of rhenium in hydrothermal solutions, Chem. Geol. 158 (1999) 245-256.

[32] Y. Xiong, S.A. Wood, Experimental quantification of hydrothermal solubility of platinum-group elements with special reference to porphyry copper environments, Mineral. Petrol. 68 (2000) 1-28.

[33] K. Righter, R.J. Walker, P.W. Warren, The origin and significance of highly siderophile elements in the lunar and terrestrial mantles, in: R.M. Canup, K. Righter (Eds.), Origin of the Earth and Moon, University of Arizona Press, Tucson, AZ, 2000, pp. 291-322.

[34] S.R. Hart, G.E. Ravizza, Os partitioning between phases in lherzolite and basalt, in: A. Basu, S.R. Hart (Eds.), Earth Processes. Reading the Isotopic Code, AGU Geophys. Monogr. 95 (1996) 123-134.

[35] C.E. Martin, G.J. Wasserburg, D.A. Papanastassiou, C.L. Peach, Os isotopic composition of sulfide globules from MORB, EOS Trans. AGU 74 (1993) 121.

[36] E.W. Dewing, F.D. Richardson, Thermodynamics of mixtures of ferrous sulfide and oxide, J. Iron Steel Inst. 4 (1960) 446-450.

[37] D.C. Hilty, W. Crafts, Liquidus surface of the Fe-S-O system, J. Metals 194 (1952) 1307-1312.

[38] V.C. Kress, Thermochemistry of sulfide liquids. I: the system O-S-Fe at 1 bar, Contrib. Mineral. Petrol. 127 (1997) 176-186.

[39] M. Stofko, J. Schmiedl, T. Rosenquist, Thermodynamics of Fe-S-O melts at $1200^{\circ} \mathrm{C}$, Scand. J. Metall. 3 (1974) $113-118$.

[40] W.L. Griffin, Z.V. Spetsius, N.J. Pearson, S.Y. O'Reilly, In situ Re-Os analyses of sulfide inclusions in kimberlitic olivine: new constraints on depletion events in the Siberian lithospheric mantle., Geochem. Geophys. Geosyst. 3 (2002) 2001 GC000287.

[41] M.R. Wilson, T.K. Kyser, R. Fagan, Sulfur isotope systematics and platinum group element behavior in REEenriched metasomatic fluids: A study of mantle xenoliths from Dish Hill, California, USA, Geochim. Cosmochim. Acta 60 (1996) 1933-1942.

[42] M.R. Handler, V.C. Bennett, T.M. Esat, The persistence of off-cratonic lithospheric mantle: Os isotopic systematics of variably metasomatised southeast Australian xenoliths, Earth Planet. Sci. Lett. 151 (1997) 61-75.

[43] V.C. Bennett, M.D. Norman, M.O. Garcia, Rhenium and platinum group element abundances correlated with mantle source components in Hawaiian picrites: sulfides in the plume, Earth Planet. Sci. Lett. 183 (2000) 513-526.

[44] J.-P. Lorand, O. Alard, Platinum group element abundances in the upper mantle: new constraints from in situ and whole-rock analyses of Massif Central xenoliths (France), Geochim. Cosmochim. Acta 65 (2001) 2789-2806.

[45] O. Alard, J.-P. Lorand, J.P. Jackson, S.Y. O'Reilly, Nonchondritic distribution of the highly siderophile elements in mantle sulfides, Nature 407 (2002) 891-894.

[46] O. Alard, N.J. Pearson, W.L. Griffin, J.-P. Lorand, S.Y. O'Reilly, New insights into the Re-Os systematics of subcontinental lithospheric mantle from in situ analysis of sulphides, Earth Planet. Sci. Lett. 203 (2002) 651-663.

[47] D.G. Pearson, S.B. Shirey, J.W. Harris, R.W. Carlson, Sulphide inclusions in diamonds from the Koffiefontein kimberlite, S. Africa: constraints on diamond ages and mantle Re-Os systematics, Earth Planet. Sci. Lett. 160 (1998) 311-326.

[48] D.G. Pearson, S.B. Shirey, G.P. Bulanova, R.W. Carlson, H.J. Milledge, Re-Os isotope measurements of single sulfide inclusions in a Siberian diamond and its nitrogen aggregation systematics, Geochim. Cosmochim. Acta 63 (1999) 703-711.

[49] C.-T. Lee, R.L. Rudnick, Compositionally stratified cratonic lithosphere: petrology and geochemistry of peridotite xenoliths from the Labait tuff cone, Tanzania, in: J.J. Gurney, S.R. Richardson (Eds.), Proc. 7th Int. Kimberlite Conf., 1998.

[50] W. Sun, R.J. Arculus, V.C. Bennett, S.M. Eggins, R.A. Binns, Evidence for rhenium enrichment in the mantle wedge from submarine arc-like volcanic glasses (Papua New Guinea), Geology 31 (2003) 845-848.

[51] J.C. Lassiter, Rhenium volatility in subaerial lavas: constraints from subaerial and submarine portions of the HSDP-2 Mauna Kea drillcore, Earth Planet. Sci. Lett. 214 (2003) 311-325.

[52] W. Sun, V.C. Bennett, S.M. Eggins, V.S. Kamenetsky, R.J. Arculus, Enhanced mantle-to-crust rhenium transfer in undegassed arc magmas, Nature 422 (2003) 294-297. 
[53] K. Righter, J.T. Chesley, J. Ruiz, D. Giest, Behavior of Re during magma fractionation: an example from Volcan Alcedo, Galapagos, J. Petrol. 39 (1998) 785-795.

[54] K. Righter, E.H. Hauri, Compatibility of rhenium in garnet during mantle melting and magma genesis, Science 28 (1998) 1737-1741.

[55] K.H. Schmidt, P. Bottazzi, R. Vannucci, K. Mengel, Trace element partitioning between phlogopite clinopyroxene and leucite lamproite melt, Earth Planet. Sci. Lett. 168 (1999) 287-299.

[56] I.S.E. Carmichael, R.A. Lange, J.F. Luhr, Minettes and related lavas in the Mascota Volcanic Field, Jalisco, Mexico, Contrib. Mineral. Petrol. 126 (1996) 257-263.

[57] M.I. Smoliar, R.J. Walker, J.W. Morgan, Re-Os isotope constraints on the age of Group IIA, IIIA, IVA, and IVB iron meteorites, Science 271 (1996) 1099-1102.

[58] J.T. Chesley, J. Ruiz, Crust-mantle interaction in large igneous provinces: implications from the Re-Os isotope systematics of the Columbia River flood basalts, Earth Planet. Sci. Lett. 154 (1998) 1-11.

[59] M. Molzahn, L. Reisberg, G. Worner, Os, Sr, Nd, Pb, O isotope and trace element data from the Ferrar flood basalts, Antarctica: evidence for an enriched subcontinental lithospheric source, Earth Planet. Sci. Lett. 144 (1996) 529-546.

[60] J.C. Lassiter, J.F. Luhr, Osmium abundance and isotope variations in mafic Mexican volcanic rocks: Evidence for crustal contamination and constraints on the geochemical behavior of osmium during partial melting and fractional crystallization, Geochem. Geophys. Geosyst. 2 (2001) 2001-03-14.

[61] P.R. Hooper, C.J. Hawkesworth, Isotopic and geochemical constraints on the origin and evolution of the Columbia River Basalt, J. Petrol. 34 (1993) 1203-1246.

[62] S.A. Nelson, E. Gonzalez-Caver, T.K. Kyser, Constraints on the origin of alkaline and calc-alkaline magmas from the Tuxtla Volcanic field Veracruz, Mexico, Contrib. Mineral. Petrol. 122 (1995) 191-211.

[63] B.K. Nelson, S.W. Nelson, A.B. Till, Nd- and Sr-isotope evidence for Proterozoic and Paleozoic crustal evolution in the Brooks Range, Northern Alaska, J. Geol. 101 (1993) 435-450.

[64] S. Esperanca, R.W. Carlson, S.B. Shirey, D. Smith, Dating crust-mantle separation: Re-Os isotopic study of mafic xenoliths from central Arizona, Geology 25 (1997) 651-654.

[65] H. Becker, S.B. Shirey, R.W. Carlson, Effects of melt percolation on the Re-Os systematics of peridotites from a Paleozoic convergent plate margin, Earth Planet. Sci. Lett. 188 (2001) 107-121.

[66] A. Büchl, G. Brügmann, V.G. Batanova, C. Münker, A.W. Hofmann, Melt percolation monitored by Os isotopes and HSE abundances: a case study from the mantle section of the Troodos Ophiolite, Earth Planet. Sci. Lett. 204 (2002) 385-402.

[67] K.W. Burton, P. Schiano, J.-L. Birck, C.J. Allègre, M. Rehkamper, A.N. Halliday, J.B. Dawson, The distribution and behaviour of rhenium and osmium amongst mantle minerals and the age of the lithospheric mantle beneath Tanzania, Earth Planet. Sci. Lett. 183 (2000) 93-106.

[68] L. Reisberg, J.-P. Lorand, Longevity of sub-continental mantle lithosphere form osmium isotope systematics in orogenic peridotite massifs, Nature 376 (1995) 159-162.

[69] L.C. Reisberg, C.J. Allègre, J.M. Luck, The Re-Os systematics of the Ronda Ultramafic Complex of southern Spain, Earth Planet. Sci. Lett. 105 (1991) 196-213.

[70] M. Roy-Barman, J.-M. Luck, C.J. Allègre, Os isotopes in lherzolite massifs and mantle heterogeneities, Chem. Geol. 130 (1996) 55-64. 